Article

\title{
CSR Actions in Companies and Perception of Their Reputation by Managers: Analysis in the Rural Area of an Emerging Country in the Banking Sector
}

\author{
Jesús Ángel Del Brío ${ }^{1, *(1)}$ and Edmundo Lizarzaburu Bolaños 2 (1) \\ 1 Escuela Politéncia, Universidad de Oviedo, Campus de Viesques, 33071 Gijón, Spain \\ 2 Universidad de ESAN, Alonso de Molina 1652, Lima 33, Peru; elizarzaburub@gmail.com \\ * Correspondence: delbrio@uniovi.es; Tel.: +34-985-18-24-58
}

Received: 8 February 2018; Accepted: 20 March 2018; Published: 22 March 2018

\begin{abstract}
This paper tests, from a managerial point of view, the influence of Corporate Social Responsibility (CSR) actions directed towards health and environmental matters over the perception of a company's reputation. The literature review suggests an absence of this kind of study focused on the banking sector of developing countries. CSR activities oriented to health and subsistence in the rural areas of emerging countries are proved to hold a positive influence on the perception of managers of the banking sector of corporate reputation. On the other hand, it has not been possible to validate whether CSR activities oriented to environmental issues (or infrastructure) in rural areas will positively influence the perception of Peruvian banking sector managers of corporate reputation. The outcomes mentioned seem plausible due to health and subsistence being undoubtedly the most valued factors among people living in rural areas, where there are the most development deficiencies. This work contributes by empirically analyzing a relationship barely addressed in the field of business administration: the influence of CSR and corporate reputation. Furthermore, the authors take the analysis to a context unexplored by previous researchers, applying the concepts to the banking sector of an emerging country.
\end{abstract}

Keywords: corporate social responsibility; corporate reputation; bank; emerging country; environment; health

\section{Introduction}

Corporate social responsibility (CSR) has evolved positioning itself as one of the leading pillars for the development of any project undertaken by a company [1]. From an academic point of view, there has been extensive research on its importance to economic benefits for both company and community development. Furthermore, as empirical evidence shows, the actions of CSR have an impact on the reputation of the company (CR). In developed countries, it is becoming increasingly evident that CSR practices may have positive consequences regarding both the internal and external development of companies, improving confidence in them [2] and reinforcing their reputation [3]. However, research on this topic is conducted within the context of developed countries and focuses on the productive sector of the economy, overlooking the setting of emerging countries and other industries, which represents a gap in additional research.

To help reduce the research gaps mentioned above, the primary objective of this paper is to analyze the perceptions of managers of the banking sector in an emerging country about the role played by CSR in the achievement of improvement of corporate reputation [4]. This objective presents three novel aspects compared to the previously analyzed studies.

Firstly, managers' perception and capacity of influence will impact on the success of CSR actions [5]. However, the investment in CSR actions in emerging countries is very recent, so the 
results obtained will help to understand the current environment of CSR in an emerging country from the perspective of the managers responsible for its implementation. This fact will undoubtedly be used to analyze whether the influence of managers will affect, positively or negatively, the behavior of the company regarding CSR [5].

Secondly, the study of the effects of CSR in the financial sector has been historically inferior compared to other industries, specifically the chemical or pharmaceutical industries [6]. This is not reasonable due to the relevant role played by the financial sector in economic development. Although the absence of actions in favor of CSR can achieve short-term profits, these gains collide with the opportunity cost of losing reputation and potential benefits. In this way, CSR becomes a precious asset of the financial sector. The choice of commercial banks as a framework for this study responds to the challenge the financial industry is going through to repair the adverse effect the economic crisis has caused on the perceptions of banking institution stakeholders by generating a feeling of fear among banking clients about the security of their investments and financial assets. This has happened not only in developed countries, but also in emerging countries [6]. Governments and banking regulators have tried to offer solutions, most of them aiming at improving the quality of financial assets through legal reforms to solve liquidity problems. However, the decisions taken to respond to the interests of the community, facilitating improvement actions directed towards all stakeholders are very scarce. Emerging countries, such as Peru, where the banking sector has a decisive role as a growth driver, highly value CSR actions.

The final novelty of the paper is that if managers consider CSR actions as a tool to improve the reputation of the company, it will imply that socially responsible behaviors enhance the performance of the company. Meaning managers will be proactive in promoting CSR initiatives when they align with their instrumental interests of increasing shareholder value and expanding the company's competitiveness and profitability [7].

The paper has the following structure: Firstly, the authors explain the CSR actions related to sustainable development carried out in rural areas by the Peruvian banking sector and their relationship to corporate reputation from the management's point of view. In the third section, the methodology for testing the hypotheses proposed in the theoretical part is described. Then, the primary results of the analysis are shown and finally, the authors present their conclusions.

\section{CSR Actions Related to the Rural Sector and Their Influence on CR of the Peruvian Banking Sector}

Research on CSR has shown that more and more companies in developed countries consider CSR as a priority and even a source of competitive advantage [8,9]. On the other hand, the analysis of this topic in emerging countries is still more incipient.

For a better perspective on how emerging countries firms understand CSR, it is essential to analyze the perception of the decision-makers of the organization: managers [10]. Their encouragement and support regarding CSR activities are transcendental to achieve a successful outcome; this justifies their status as a unit of analysis when studying CSR [11]. Managers promote, defend, and develop CSR actions within a company. They also lead the organization's commitment to CSR by allocating its resources to different programs and practices, in parallel aligning these activities to the objectives of the business [7].

Previous studies have criticized companies due to the symbolic reasons behind their participating in CSR activities. For instance, Porter and Kramer [12] comment that most companies' CSR initiatives are merely superficial rather than strategic or operational. However, they are a relevant dimension to the business strategy, which is why managers should not regard them as a simple trend [13]. Summing up, in the first place, managers should acknowledge the importance of CSR actions within the company with a clear objective and a focus on sustainability. This will expand when decision-makers realize that CSR initiatives align with their interests of creating shareholder value and increasing the 
competitiveness and profitability of the organization, that will consequently lead to improving their position in the company [7], as well as reducing costs as part of greater operational efficiency.

A strategic reflection on CSR leads to positive effects on multiple dimensions of corporate reputation. Literature identified some of the results as enhanced management quality, managerial ability, and business leadership [14-16], improved product quality and customer satisfaction [17,18], and the reinforcement of stakeholders' confidence based on a stronger corporate image $[19,20]$ and competitive positioning [21].

However, several authors indicate that perception of the impact of CSR on the variables mentioned above is biased; conditioned by the location of the company $[2,3,8]$. Based on this, it appears necessary to study the perception of corporate executives from developing countries. Then it is essential to analyze whether, in emerging economies, where the consideration of CSR is in an embryonic state, it is perceived as relevant to the success of the company by managers to continue promoting these practices in the company. In this article, we focus on the perception of the importance of CSR in the rural areas of an emerging country.

Globalization, demographic change, and rural migration are a few of the numerous challenges the majority of rural areas of emerging countries face for their development. The policies aimed at those areas should strengthen their competitive activities and create more opportunities for growth. In this context, the companies seeking rural development should assess the strengths and weaknesses of the neighboring communities before taking a course of action. The literature review prompted us to organize the CSR efforts of companies of multiple sectors into three types: health and subsistence programs, environment and infrastructure, and education [22,23]. In fact, at the beginning of the new millennium, World Leaders met at the United Nations to give shape to the broad vision of combating poverty in its many dimensions. This vision translated into the eight Millennium Development Goals (MDGs). MDGs were replaced by the new Sustainable Development Goals (SDGs) of the United Nations (UN) in 2015, which became effective from 1 January 2016. The seventeen SDGs differ from MDGs because they are broader in number, represent larger aspirations and present a relevant program for all people in all countries so that nobody is left behind. The current agenda requires addressing the three dimensions of sustainable development holistically. Out of the seventeen SDGs, this paper will analyze the actions implemented by companies regarding health and subsistence and environment and infrastructure. Health and subsistence are two of the most critical factors for inhabitants of rural areas due to the significant deficiencies in development which exist there. Organizations that act regarding the mentioned factors are likely to achieve an enhanced corporate reputation because of the leadership attributed to the business and the boosting of brand image, higher levels of customer satisfaction derived from the fulfillment of buying socially responsible products and hence a greater reliance on competition $[24,25]$. However, there is hardly any empirical evidence to prove this relationship. Furthermore, the available data focuses on developed countries and productive sectors. Verbeteen, Gamerschlag and Möller evidence the positive relationship between CSR actions, including health and subsistence activities, and the corporate reputation of German companies [26]. Additionally, Droppert and Bennett demonstrate that concentrating efforts on health improves corporate reputation of relatable sectors, such as the chemical sector [27].

For different settings, such as emerging countries, the volume of identified research is smaller. It is important to emphasize that regarding the above-mentioned study by Droppert and Bennett, the authors highlight the applicability of their theory to low and middle income developing countries such as Peru [26]. Previous findings indicate an extensive development of CSR within the management model of financial organizations, which incorporates four interrelated dimensions: corporate governance, social focus, stakeholder relationship and social work focused on health and environmental care, among other topics; that lead to an enhanced image abroad [28]. Finally, Pradhan and Ranjan conducted a study of CSR programs after rural development in India. The sample considered both public and private companies from different sectors [29]. A similar investigation was conducted in the country years before [30]. However, in contrast to said investigation, Pradhan and 
Ranjan took the financial sector into account. The findings indicated that a hundred percent of the analyzed companies focused their efforts on the health issue; although, they did not relate this data to corporate reputation.

This investigation originated from a case study of the companies of the Peruvian banking system. From the gathered data, the authors detected an increasing CSR activity centered on health and subsistence matters in rural areas. This finding shows managers' commitment to the issues in question in emerging economies such as Peru. Appendix A summarizes the activities carried out by the four most prominent banks in Peru in aid for health and subsistence.

From the few empirical analyses carried out in the financial sector and developing countries, as well as from the case studies of the Peruvian banking sector, the authors issue the following hypothesis:

Hypothesis 1 (H1). Corporate social responsibility for health and subsistence in rural areas will positively influence managers' perception regarding corporate reputation in the Peruvian banking sector.

The second action involving the rural areas is the construction of infrastructure. Water supply and drainage, afforestation and reforestation, and spill control are highly rewarded activities. Organizations that carry out activities in favor of either infrastructure and environment can achieve enhanced corporate reputation $[24,25]$. The management perception of this achievement, if positively influenced, would spark higher levels of investment in the mentioned actions. Infrastructure and environmental activities enable the zone where they are executed to access further development; from there onwards, part of the population could become future clients of the company with a higher value attributed to its products, as well as a better opinion of management quality and business leadership [23,24].

The empirical evidence in this field is an extension of the analysis of health and subsistence. The distribution of CSR programs analyzed in India considered a sample of multiple industrial companies that provided public information [30]. Applying the content analysis to the information gathered from the websites and annual sustainability reports of the selected companies, the authors discovered that an increasingly relevant percentage of them focused efforts on CSR activities of infrastructure and environment to promote rural development. Concerning the financial sector, a previous study mentions the relevance of environmentally-focused social work due to it enhancing the corporate image abroad [28]. Finally, a more recent investigation of CSR programs in favor of rural development in India assessed environmental infrastructure [29]. To carry out this research, the authors considered public and private companies from multiple sectors, just like previous investigations [30]; however, it also examines financial organizations [29]. The results of the tests showed that a hundred percent of the sampled companies directed efforts towards health issues, whereas only $50 \%$ of the businesses oriented actions towards infrastructure and environment. The relation between the variables and corporate reputation was not analyzed.

Through the case study, the authors were able to verify that the observed banks carried out actions in favor of infrastructure and environment. Appendix A compiles the infrastructure and environment activities conducted by the four most famous banks of Peru.

Based on the references that support the relationship between corporate reputation and CSR actions of infrastructure and environment, as well as of the data extracted from the case analysis, the authors formulate the following hypothesis:

Hypothesis 2 (H2). Corporate social responsibility for environment and infrastructure in rural areas will positively influence the managers' perception of corporate reputation in the Peruvian banking sector.

The final model proposed for comparison is summarized graphically in Figure 1. 


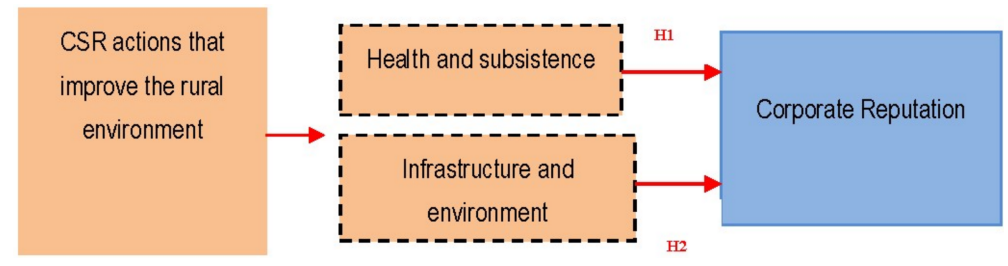

Figure 1. Model of actions that improve the rural environment and their effects on corporate reputation (compiled by authors).

\section{Methodology}

A quantitative methodology was used to compare the hypotheses presented in this paper. The empirical research began in March 2016 with the presentation of the initial questionnaire to the directors of the Association of Banks of Peru (ASBANC). This pilot served to prepare the final survey.

The changes made to the original questionnaire involve adjustments to the writing and presentation style of the questions. The final survey was composed of different sections. The first part assesses economic variables concerning the banks' branches in an open-ended question format. This part gathers data on the number of employees, benefits, market share, etc. The rest of the questionnaire was composed of close-ended questions in the form of a Likert scale ranging from 1 (Very low) to 5 (Very high) to value the intensity of the responses. The questions are related to CSR actions concerning the triple bottom line based on economic, social, and environmental issues. Likewise, the survey appraised the perception of the financial institutions regarding corporate reputation and business confidence sourced from CSR activities. Appendix B exhibits the questionnaire employed for this research.

Later on, the directors of ASBANC provided the authors with data of the banks operating in Peru up to January 2016, making up a total of seventeen banks (see Table 1); as well as the contact information of 1745 executive officers of the branches of the banks. These key individuals were selected as the target population of the study because the authors sought to study the management's perception of CSR and corporate reputation. As justified in the theory section, if managers perceive that CSR actions have a positive influence on corporate reputation they will promote such activities among the rest of the internal stakeholders, especially the employees $[7,13]$.

Table 1. Banks in Peru (January 2016, compiled by authors).

\begin{tabular}{lllll}
\hline $\begin{array}{l}\text { 1. Banco de Crédito del } \\
\text { Perú }\end{array}$ & 2. Banco Continental & 3. Scotiabank Perú & 4. Interbank & $\begin{array}{l}\text { 5. Mibanco } \\
\text { Finanzas }\end{array}$ \\
\hline 7. Banco Financiero & 8. Banco GNB & $\begin{array}{l}\text { 9. Banco Falabella } \\
\text { Perú }\end{array}$ & $\begin{array}{l}\text { 10. Banco } \\
\text { Santander Perú }\end{array}$ & $\begin{array}{l}\text { 11. Citibank } \\
\text { 12. Banco Ripley }\end{array}$ \\
\hline $\begin{array}{l}\text { 13. Banco de Comercio } \\
\text { 14. Banco Azteca Perú }\end{array}$ & 15. Banco Cencosud & 16. Banco ICBC & $\begin{array}{l}\text { 17. Deutsche } \\
\text { Bank Perú }\end{array}$ \\
\hline
\end{tabular}

In April 2016, the questionnaire was sent by e-mail to the 1745 managers of the full-service banks with a message explaining the relevance of the study. It also included a promise from the authors to send a summary of the results to everyone who collaborated. Additionally, to give the e-mail more credibility, the document with the results of the case study previously published by ASBANC was attached. The participants were sent reminders in May 2016. The data gathering process finished in July 2016 with 112 valid responses (6.41\%). The following sub-sections present the technical file and statistical validation of the response rate achieved, followed by an explanation of the variables.

\subsection{Technical Data and Statistical Validity}

Table 2 shows the records of the study, i.e., the universe or target population, geographical area and timeframe of the research, unit, size, sample error and confidence level. 
Table 2. Technical Data.

\begin{tabular}{|c|c|c|c|}
\hline \multicolumn{4}{|c|}{ TECHNICAL DATA } \\
\hline \multicolumn{2}{|r|}{ Characteristics } & \multicolumn{2}{|r|}{ Survey } \\
\hline 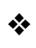 & Universe or target population & * & Banking entities operating in Peru (offices) \\
\hline * & Area geographical/temporal & 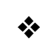 & All Peruvian territory/year 2016 \\
\hline 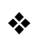 & Sample unit & * & Bank office \\
\hline 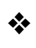 & Sample size & $*$ & 112 valid surveys \\
\hline 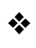 & Sampling error/confidence level & $*$ & $8.9 \%$ sampling error $/ 95 \%$ confidence \\
\hline \& & Date of completion of field work & 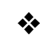 & 1 April 2016 to 30 July 2016 \\
\hline * & Respondent & * & Managing Director of Banking Office \\
\hline
\end{tabular}

The expression $\mathrm{n}=\frac{\mathrm{Z}^{2} \times \mathrm{N} \times \mathrm{p} \times(1-\mathrm{p})}{(\mathrm{N}-1) \times \mathrm{e}^{2}+\mathrm{e}^{2} \times \mathrm{p} \times(1-\mathrm{p})}$ was used to calculate the sampling error. $\mathrm{N}$ stands for the population size (1745), $\mathrm{n}$ is the sample size (112), $\mathrm{Z}$ at a confidence level of $95 \%$ takes the value of 1.96, $\mathrm{P}$ is the population that holds the characteristic. As it is unknown, the authors bet on the worst case, where $\mathrm{p}=\mathrm{q}=0.5$, and $\mathrm{e}$ is the sampling error, the variable to calculate. After applying the formula, the resulting error rate is of 0.0896 . The error rate is high because the response rate was low. However, errors below 0.1 are statistically acceptable [31]. Table 2 summarizes the technical data.

To analyze whether the sample is representative of the population, the frequency distributions are shown by gender and by age (Tables 3 and 4 ).

Table 3. Representativeness of the sample by gender.

\begin{tabular}{ccccc}
\hline & Population (No.) & Population (\%) & Sample (No.) & Sample (\%) \\
\hline Men & 1135 & $65 \%$ & 65 & $58 \%$ \\
Women & 610 & $35 \%$ & 47 & $42 \%$ \\
Total & 1745 & $100 \%$ & 112 & $100 \%$ \\
\hline
\end{tabular}

Table 4. Representativeness of the sample by gender.

\begin{tabular}{ccccc}
\hline & Population (No.) & Population (\%) & Sample (No.) & Sample (\%) \\
\hline Under 25 years & 349 & $20 \%$ & 20 & $18 \%$ \\
From 25 to 34 years & 890 & $51 \%$ & 52 & $46 \%$ \\
From 35 to 44 years & 349 & $20 \%$ & 18 & $16 \%$ \\
From 45 to 54 years & 105 & $6 \%$ & 16 & $14 \%$ \\
More than 55 years & 52 & $3 \%$ & 6 & $5 \%$ \\
Total & 1745 & $100 \%$ & 112 & $100 \%$ \\
\hline
\end{tabular}

Two logit analyses were performed to evaluate the representativeness of the sample with more reliability. The dependent variable was the probability of response [32]. The independent variable in the first logit was gender, measured by the number of responses from men and women; whereas, in the second logit, the number of responses by age group was the independent variable. The number of responses did not enter the model in any of the analyses. This result proved the objectiveness of the sample and guaranteed its external validity.

\subsection{Measurement Scales}

A multiple indicators approach was followed to construct the measurement scales of the concepts used in this work. Thus, each concept was measured using various items or variables. In addition to the theoretical contributions from the cited literature, the authors employed the scales of the works mentioned below as reference in the process of developing the measurement scales of each of the dimensions assessed. 


\subsubsection{Perception of Actions for Health and Subsistence in the Rural Area by Managers}

Four items measure management's perception of the importance of actions for health and subsistence in the rural area. Following previous research $[27,30]$, it is clear that the determinants of such activities are the number of actions carried out, their degree of importance and impact and the monetary expenditure. The survey assessed the mentioned items with a Likert scale of 1 to 5 detailed as follows: (1) Perception of the importance of CSR actions oriented to health in rural areas (IMPORTANCIASALUD), range from 1 (Not important) to 5 (Very important); (2) Perception of number of CSR actions oriented to health in rural areas (CANTIDAD SALUD), range from 1 (Few actions) to 5 (Many actions); (3) Perception of the degree of social impact in CSR actions directed to health in rural areas (IMPACTOSALUD), range from 1 (Very low impact) to 5 (Very high impact); and (4) Perception of the investment in CSR actions that improve health in rural areas (INVERSIONSALUD), range from 1 (Little investment) to 5 (Big investment).

\subsubsection{Actions of Infrastructure and the Environment in the Rural Area}

The following group of questions refers to the actions oriented towards the environment and infrastructure in rural areas. Four items measure the perception of the importance of the related activities [33]. The survey assessed the mentioned items with a Likert scale of 1 to 5 detailed as follows: (1) Perception of importance of CSR actions directed to environmental infrastructure in rural areas (IMPORTANCIAMA), range from 1 (Not important) to 5 (Very important); (2) Perception of number of CSR actions oriented to environment and infrastructure in rural areas (CANTIDADMA), range from 1 (Few actions) to 5 (Many actions); (3) Perception of degree of social impact of CSR actions toward infrastructure and environment in rural areas (IMPACTOMA), range from 1 (Low impact) to 5 (High impact); and (4) Perception of investment in CSR actions that improve the rural environment and infrastructure (INVERSIONMA), range from 1 (Little investment) to 5 (Big investment).

\subsubsection{CR Actions}

The third group of questions assesses the perception of the corporate reputation of the company. Literature suggests four different dimensions that influence the said variable: (1) perception of improvement of management quality, managerial ability and business leadership [14-16] (RCGESTION); (2) stakeholder perception of corporate image [17,18] (RCIMAGEN); (3) perception of improvement in product quality and customer satisfaction $[19,20]$ (RCSATISFACCION) and (4) stakeholder perception of confidence regarding competitors [21] (RCCONFIANZA). The variables were evaluated on a Likert scale (1-5).

\section{Results}

The proposed scales were subject to evaluation. For this, the authors conducted principal component analyses (PCA), exploratory factor analyses (EFA) and confirmatory factor analyses (CFA) using structural equation modeling. The statistic software employed consisted of IBM/SPSS version 24 for Windows and EQS version 6.1 for Windows. Later, the authors used the structural equation modeling statistical technique to test the proposed model. Said method allows testing complex models of relationships between variables considering all of them simultaneously. Table 5 displays the average and standard deviation of each of the items employed. Table 6 shows the correlations between the variables giving a first idea of the relationships between them.

Harman's single factor test was used to verify there was no common method bias (CMB), to do this the items of the scale are constrained to just one. If all variables weigh a single factor or any factor explains most of the variance, then $\mathrm{CMB}$ is an issue. The importance of this method has been shown in the literature [34]. The exploratory factor analyses carried out are shown in Tables 7 and 8 . Three factors were generated using the eigenvalues $>1$ rule. Each one of them explains $32.6 \%, 15.58 \%$ and $11.79 \%$ of the variance of the data. The authors conclude that the results are not affected by the CMB 
because there is no single factor and neither does the first factor represent a majority of the variance of the data. Furthermore, the analysis reflected accordance between the composition of the scales and the starting assumptions. In other words, it revealed the existence of three factors measured by the items suggested in the theoretical analysis explained previously.

Table 5. Descriptive Statistics.

\begin{tabular}{cccccc}
\hline & N & Minimum & Maximum & Mean & Standard Deviation \\
\hline Importanciasalud & 112 & 1 & 4 & 2.54 & 0.721 \\
Cantidadsalud & 112 & 1 & 4 & 3.01 & 0.530 \\
Impactosalud & 112 & 1 & 5 & 3.06 & 0.693 \\
Inversionsalud & 112 & 1 & 5 & 3.03 & 0.694 \\
Importanciama & 112 & 1 & 4 & 3.23 & 0.582 \\
Cantidadma & 112 & 1 & 4 & 3.31 & 0.612 \\
Impactoma & 112 & 1 & 4 & 3.30 & 0.550 \\
Inversionma & 112 & 1 & 5 & 3.28 & 0.636 \\
Rcgestión & 112 & 2 & 5 & 3.78 & 0.650 \\
Rcimagen & 112 & 2 & 5 & 3.73 & 0.632 \\
Rcsatisfacción & 112 & 2 & 5 & 3.81 & 0.685 \\
\hline
\end{tabular}

Subsequently, the authors used the Structural Equation Modeling (SEM) to perform a confirmatory factor analysis on the proposed model. Also, for the estimation, the Robust Maximum Likelihood method was employed [35]. This procedure granted the model of a global adjustment proposed on various statistics corrected to assume non-normality. Additionally, the authors developed a regression model in which Factor 1 (Perception of actions of health and subsistence) and Factor 2 (Perception of actions of environment and infrastructure) are the determinants, while Factor 3 (Perception of Corporate reputation $\mathrm{CR}$ ) is the forecasted variable. Figure 2 shows the suggested model following the SEM method.

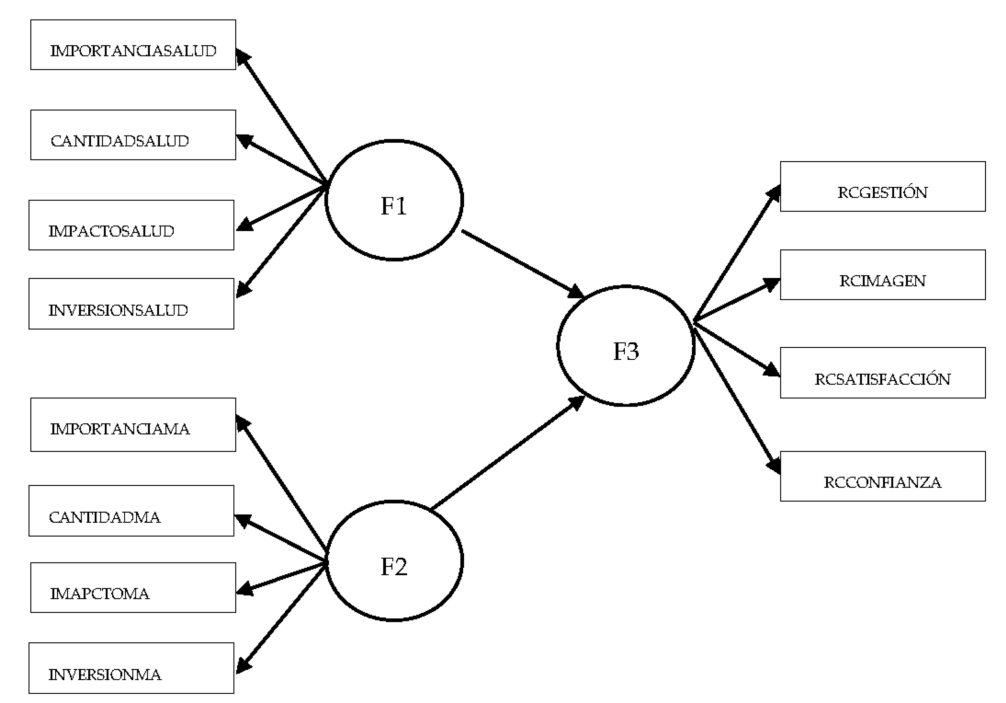

Figure 2. Model SEM between perception of actions CSR of health and environment and perception of corporate reputation.

Table 9 shows the statistics that explain the quality of fit of the proposed scales of the model. Figure 3 presents the final results of the model, including the factorial weights of the items over their respective factors, as well as the coefficients of the causal model of Factor 1 and Factor 2 over Factor 3 . In the model, $t$ values are in parentheses. When higher than 1.96 , they imply significance for a confidence interval of $95 \%$. 
Table 6. Correlations.

\begin{tabular}{|c|c|c|c|c|c|c|c|c|c|c|c|c|}
\hline & $\begin{array}{l}\text { IMPORTANCI } \\
\text { ASALUD }\end{array}$ & $\begin{array}{l}\text { CANTIDA } \\
\text { DSALUD }\end{array}$ & $\begin{array}{l}\text { IMPACT } \\
\text { OSALUD }\end{array}$ & $\begin{array}{l}\text { INVERSIO } \\
\text { NSALUD }\end{array}$ & $\begin{array}{l}\text { IMPORT } \\
\text { ANCIMA }\end{array}$ & $\begin{array}{l}\text { CANTID } \\
\text { ADMA }\end{array}$ & $\begin{array}{l}\text { IMPAC } \\
\text { TOMA }\end{array}$ & $\begin{array}{l}\text { INVERS } \\
\text { IONMA }\end{array}$ & $\begin{array}{l}\text { RCGES } \\
\text { TIÓN }\end{array}$ & $\begin{array}{l}\text { RCIMA } \\
\text { GEN }\end{array}$ & $\begin{array}{l}\text { RCSATIS } \\
\text { FACCIÓN }\end{array}$ & $\begin{array}{c}\text { RCCONFI } \\
\text { ANZA }\end{array}$ \\
\hline IMPORTANCIASALUD & 1 & & & & & & & & & & & \\
\hline CANTIDADSALUD & $0.572 * *$ & 1 & & & & & & & & & & \\
\hline IMPACTOSALUD & $0.478^{* *}$ & 0.580 ** & 1 & & & & & & & & & \\
\hline IMPORTANCIAMA & $0.470^{* *}$ & $0.429 * *$ & $0.525 * *$ & $0.537 * *$ & 1 & & & & & & & \\
\hline CANTIDADMA & 0.376 ** & 0.267 * & 0.410 ** & $0.346^{* *}$ & $0.678 * *$ & 1 & & & & & & \\
\hline IMPACTOMA & 0.405 ** & 0.374 ** & 0.369 ** & $0.445^{* *}$ & 0.657 ** & $0.588^{* *}$ & 1 & & & & & \\
\hline INVERSIÓNMA & $0.474^{* *}$ & $0.624 * *$ & $0.474^{* *}$ & $0.436 * *$ & $0.551 * *$ & $0.497^{* *}$ & $0.401 * *$ & 1 & & & & \\
\hline RCGESTIÓN & -0.027 & $0.236 *$ & 0.078 & $0.241 *$ & 0.079 & 0.204 & 0.189 & 0.097 & 1 & & & \\
\hline RCSATISFACCIÓN & 0.142 & $0.377^{* *}$ & $0.377^{* *}$ & $0.439^{* *}$ & 0.140 & 0.035 & 0.182 & 0.328 ** & $0.611 * *$ & $0.505^{* *}$ & 1 & \\
\hline RCCONFIANZA & $-0.454^{* *}$ & 0.145 & 0.168 & 0.139 & 0.013 & -0.038 & 0.040 & 0.074 & $0.466^{* *}$ & $0.557^{* *}$ & $0.436^{* *}$ & 1 \\
\hline
\end{tabular}


Table 7. Variance of factors.

\begin{tabular}{cc}
\hline Factors & Variance Explained \\
\hline 1 & 32,601 \\
2 & 15,587 \\
3 & 11,790 \\
\hline
\end{tabular}

Table 8. Rotated ${ }^{\text {a }}$ Component Matrix.

\begin{tabular}{cccc}
\hline & \multicolumn{3}{c}{ Component } \\
\cline { 2 - 4 } & $\mathbf{1}$ & $\mathbf{2}$ & $\mathbf{3}$ \\
\hline IMPORTANCIASALUD & 0.783 & 0.196 & 0.074 \\
CANTIDADSALUD & 0.749 & 0.288 & 0.024 \\
IMPACTOSALUD & 0.728 & 0.300 & 0.449 \\
INVERSIONSALUD & 0.687 & 0.343 & -0.077 \\
IMPORTANCIAMA & 0.308 & 0.681 & 0.433 \\
CANTIDADMA & 0.228 & 0.838 & -0.071 \\
IMPACTOMA & 0.205 & 0.803 & 0.119 \\
INVERSIÓNMA & 0.381 & 0.795 & 0.105 \\
RCGESTIÓN & 0.037 & 0.029 & 0.764 \\
RCIMAGEN & 0.217 & 0.095 & 0.580 \\
RCSATISFACCIÓN & 0.043 & 0.135 & 0.862 \\
RCCONFIANZA & 0.330 & -0.066 & 0.630 \\
\hline
\end{tabular}

Extraction method: main component analysis. Rotation method: Varimax with Kaiser normalization. ${ }^{\text {a }}$ The rotation has turned into 8 iterations.

Table 9. Summary of quality of fit for robust method.

\begin{tabular}{lclr}
\hline Satorra-Bentler Scaled Chi-Square & 67.6392 & Comparative Fit Index (CFI) & 0.915 \\
Degrees of Freedom & 52 & Bollen's (IFI) Fit Index & 0.924 \\
$p$ value & 0.142 & McDonald's (MFI) Fit Index & 0.926 \\
Bentler-Bonett Normed Fit Index & 0.943 & Root Mean Square Error of Approximation (RMSEA) & 0.058 \\
Bentler-Bonett Non-normed Fit Index & 0.919 & $90 \%$ Confidence Interval of RMSEA & $(0.000-0.131)$ \\
\hline
\end{tabular}

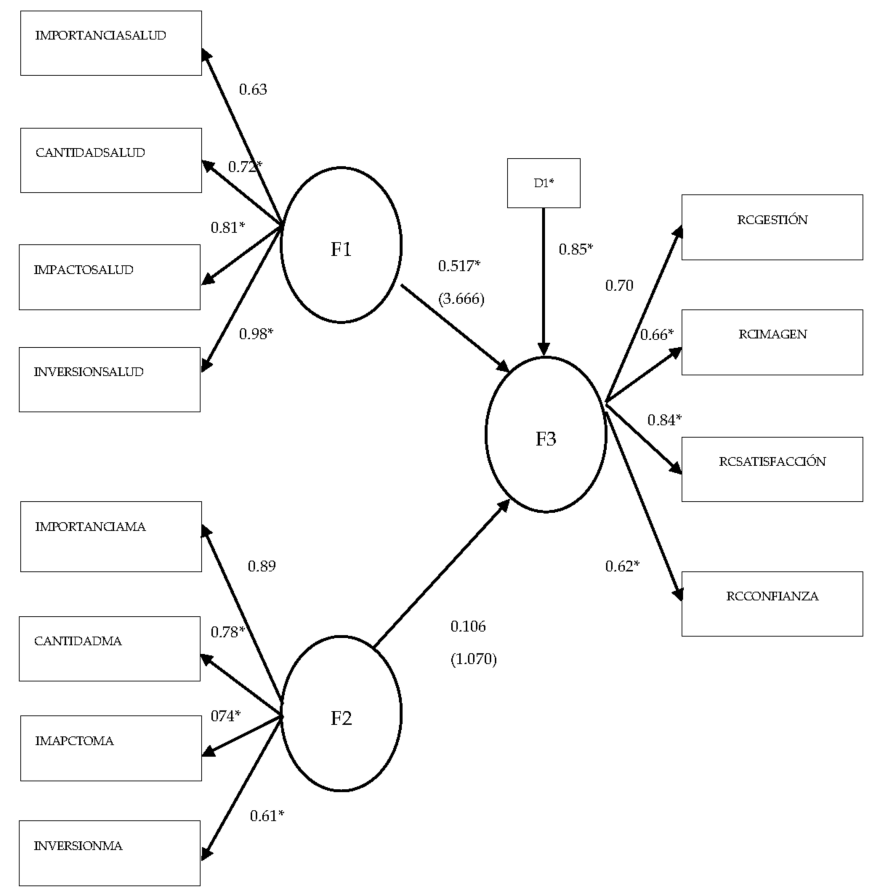

Figure 3. Results of model SEM between actions RSC of health and environment and corporate reputation (the character * indicates that the value is significant). 


\section{Discussion}

The results of the Robust Model (without assuming normality of the variables) show that the SEM model presents good fit when [36]:

(a) Probability value for the chi-square statistic of Satorra-Bentler is higher than 0.05 as occurs in the displayed results (Table 9).

(b) Bentler-Bonett Index or Normed Fit Index (NFI) and Comparative Fit Index (CFI) should be higher than 0.9 to accept the model. If they are higher than 0.95 , the model is much better. In this case, the model is acceptable because both indexes are between 0.9 and 0.95 .

(c) Root-mean-square error of approximation (RMSEA) must be, at least, smaller than 0.08; the indicator is better if it is lower than 0.05. Furthermore, confidence Interval of RMSEA must include the zero. We satisfy all these parameters (RMSEA is 0.058 , less than 0.08).

(d) Factorial weights are between 0 and 1 . According to literature, the higher the value, the better; but they must be at least higher than 0.7. However, several researchers think that this heuristic rule should not be so rigid. It is necessary for indicators with very low loads (i.e., 0.4 ) to be eliminated [37]. In the presented model, factorial weights of less than 0.7 are very close to that value. Therefore, the authors assume that the model is acceptable.

In conclusion, the model presented significance in the confirmatory factorial analysis, and thus, is suitable for the investigation's purpose. The results lead us to conclude that the selected three factors summarize the information of the items asked in the survey. The dependent variable of the model is the construct of perception of Corporate Reputation and explains $61.557 \%$ of the topics analyzed in the questionnaire. Additionally, the two independent variables are (a) Perception of actions in the rural area directed towards health and subsistence (RURALSALUDRSC), that explains $71.940 \%$ of the variance of the items and; (b) Perception of actions in the rural area oriented towards environment and infrastructure (RURALINFRAMARSC), that explains $67.458 \%$ of the variance of the items.

The causal model proved the influence of the perception of the importance of Peruvian banks' efforts to improve health and subsistence in rural areas over the perception of corporate reputation, as the researchers initially proposed. The relationship found was statistically significant at a level of $p<0.05$. Hypothesis 1 is, therefore, validated. I.e., the perception of CSR actions oriented towards health and subsistence in rural areas outside the metropolis will positively influence the perception of corporate reputation in the Peruvian banking sector. The theory section of this paper affirmed that health and subsistence are undoubtedly two of the most critical factors for people living in rural areas because they present the most significant deficiencies in development. Likewise, management sense that the CSR actions oriented to health and subsistence in rural areas certainly improve the bank's reputation. Therefore, the results support the theoretical review, which states that companies can achieve higher levels of corporate reputation through acting in favor of health and subsistence [24,25]. Additionally, the findings support the empirical results of both German companies [26] and the chemical sector [27]. The previous empirical studies of either developing countries or the banking sector were expanded with these results. The single analysis of the financial industry of developing nations discovered that $100 \%$ of the sampled companies focused efforts in health matters [29]. However, the authors did not analyze the influence on corporate reputation. For this reason, the now presented contrast supposes an improvement in the current empirical literature.

The perception of CSR actions for environment and infrastructure taken by Peruvian banks has a positive relationship with that of corporate reputation. However, this relationship is not significant. Consequently, Hypothesis 2 cannot be validated. I.e., the authors cannot confirm the conjecture of the perception of CSR actions oriented to environment and infrastructure in rural areas positively influencing the perception of the corporate reputation of the Peruvian banking sector.

Empirical evidence in this field was an extension of the analyses carried out for health. Furthermore, health and subsistence are considered the most critical factors for the rural population. Perhaps for this reason, management perceives that those actions exercise a significant and positive 
influence on the bank's corporate reputation, but those in favor of the environment or infrastructure fail to do so because they do not seem as relevant.

Following previous research in the banking sector in emerging countries [38] it was found that disclosure of environmental information increased sharply from 16\% in 2010 to $83 \%$ in 2014 in the financial sector in Bangladesh. In addition, authors reviewed Bangladesh Bank's recent fruitful initiatives on environmental disclosures, and the findings of the 12 categories had managerial implications for policy makers in corporations as well as the government. It was recommended that professional accounting bodies of Bangladesh, together with international and government policy makers, develop a separate conceptual framework for environmental accounting and reporting for the financial and non-financial sectors of the country. The authors believe these recommendations apply to Peru's financial sector since CSR actions, especially those carried out in the area of health, have a positive influence on the perception of the bank's CR. As recommended to Bangladesh, it would be impressive if banks progressed into communicating CSR towards all their stakeholders. Additionally, it would also be highly encouraging if politicians adopted public measures to encourage the dissemination of CSR actions through certified reports like the GRI. This statement is consonant with other studies carried out in developed countries that analyze the importance of sustainability reports [39].

\section{Conclusions}

This paper analyzed the relationship between CSR actions focused on sustainable development carried out by the Peruvian banking industry and their influence over CR. The perception of CSR actions can affect the construct that forms the perception of CSR in the Peruvian banking sector. This industry, in an emerging economy such as Peru, began to include CSR projects within its strategic planning from 2000 onwards. In recent years, multiple banking businesses have strengthened the presence of such programs because of the positive outcomes obtained.

Throughout the research, the authors showed the positive influence of the perception of CSR actions directed to health and subsistence in rural zones over the perception of the Peruvian banking sector's corporate reputation, supported by theoretical contributions and empirical studies; although only in either productive industries or developed countries. It has not been possible to validate the effect of CSR actions oriented to infrastructure and environment over the Peruvian banking sector's CR. This is, perhaps, because environmental care is relevant to a lesser degree in emerging economies.

The principal contribution of this work lies in the empirical analysis of a barely addressed relationship in the field of business administration: the influence of CSR on corporate reputation. Furthermore, the study is carried out in an original context, the banking sector of an emerging country. Of course, the authors are aware of the limitations of this paper, and the potential improvement to it. Firstly, the measurement of CSR and CR actions was of perception scales ranging from 1 to 5 . Other articles referenced in this study used the same procedure. However, if the research employs objective measurements, the conclusions could improve. For CSR actions, the analysis of the real economic efforts made by Peruvian banks in favor of rural areas should be complemented with reports or sourced from public information either by the company or by independent agents such as ASBANC. Likewise, rankings like MERCO could be utilized to evaluate more accurately the positioning of the banks regarding reputation among their peers. However, there is still an insufficient amount of objective data concerning CSR in emerging economies such as Peru.

On the second hand, the generalization of the results. Authors are aware that the study has been based on the perception of managers, who consider that if CSR actions can improve banking sector's CR, will involve more proactively the rest of internal stakeholders in order to raise awareness of the importance of promoting CSR actions (in our analysis, they are trying to strengthen CSR actions dedicated to infrastructures). However, we cannot extrapolate the results for external stakeholders. In the financial sector of developed countries, corporate social responsibility is solidly established due to its significant impact on society [40]. The banking sector has presented significant transformations 
in recent years and has become one of the most proactive agents in becoming involved with CSR in all its actions worldwide. However, it still has not been demonstrated if the positive response to CSR in emerging countries will be the same from the point of view of external stakeholders as it happens in developed countries. Therefore, in future research, this relationship should be explored from the point of view of customers, suppliers, and investors to prove that CSR actions in emerging countries will have the same results in banking's CR as it happens in developing countries from the point of view of and external stakeholders.

The authors assume a low response rate, and although it appears statistically sufficient, the study should also improve that aspect in the future. The researchers hope that the previous statement does not belittle a work that, from the academic research perspective, is innovative because it closes the gap between CSR and CR, applying it to a sector and a country never addressed before.

From the business perspective, this work makes a fundamental contribution by providing reasons for banks to believe that CSR actions enable them to enhance their corporate reputation. In times of crisis, when the banking sector becomes severely criticized by society, CSR activities allow them to strengthen their status by demonstrating that in addition to generating wealth, a fundamental objective for any business, they return part of what society has provided them and also contribute to a fairer distribution in depressed areas.

Author Contributions: This paper is part of a more extensive research, a doctoral thesis, prepared by Edmundo Lizarzaburu Bolaños and directed by Jesús Ángel Del Brío. The task of writing this paper was carried out by both authors.

Conflicts of Interest: The authors declare no conflict of interest.

\section{Appendix Actions of Health and Environment Carry Out by the Four Main Peruvian Banks}

The Peruvian banking sector consisted of sixteen banks in 2015-Banco de Crédito del Perú (BCP), Banco Continental (BBVA), Scotiabank Perú, Interbank, Banco Interamericano de Finanzas, Mibanco, Banco Financiero, HSBC Bank Perú, Citibank, Banco Falabella Perú, Banco Santander Perú, Banco de Comercio, Banco Ripley, Banco Azteca Perú, Banco Cencosud, Deutsche Bank Perú.

Within the group, four banks have more than $80 \%$ of the following indicators: total loans made by the entire banking system of Peru; the banks' participation in the funding market; and the total capital of the entire banking system of Peru. These four banks are Banco de Crédito del Perú (BCP), Banco Continental (BBVA), Scotiabank Perú and Interbank. Below we show the central CSR actions in health and environment carried out by these banks.

1. $\mathrm{BCP}$ has carried out activities mainly related to infrastructure and the environment. Some of them are philanthropic donations. E.g., this bank supports the Peruvian State in reducing the infrastructure gap through the "Works by Taxes" mechanism. BCP financed and submitted the project "Extension and Improvement of the Drinking Water System and Construction of the Sewage System at the town of La Encantada, located in Piura". Other actions they carry out are voluntary projects managed directly by the bank, e.g., BCP led and managed ten committees nationwide of voluntary collaborators for the construction of environmental infrastructure.

2. The CSR programs developed by BBVA are related to economic support and credits in favorable conditions for improving health and environmental conditions.

3. Scotiabank has developed projects directly related to health and environmental infrastructure in vulnerable areas. Between 2007 and 2012, the bank participated together with twelve local governments in the regions of Áncash, Arequipa, Cajamarca, Cuzco, Junin, Lambayeque, La Libertad, Lima, Moquegua, carrying out 46 projects of water and sanitation systems. Additionally, it promoted the program "Illuminate the Morning" which contributes to the implementation of projects to support the community and the conservation of the environment.

4. Interbank has implemented the following types of CSR projects directly sponsored by the banks: "Graceland" which promotes the participation of all the bank's voluntary collaborators, 
regardless of their positions or hierarchy, in groups formed by members from all areas of the institution. "Program 'Todo Terreno'" (all areas/all terrain). The purpose of this program is to facilitate access to financial services for company employees who work in rural, agricultural, or hard-to-reach areas.

\section{Appendix Survey Questions Used in This Paper}

\begin{tabular}{|c|c|c|c|c|c|}
\hline \multirow[t]{2}{*}{ Corporate Reputation } & \multicolumn{3}{|c|}{ Very Low } & \multicolumn{2}{|c|}{ Very High } \\
\hline & 1 & 2 & 3 & 4 & 5 \\
\hline \multicolumn{6}{|l|}{ Assess the importance of the quality of management and business leadership in the bank. } \\
\hline \multicolumn{6}{|l|}{ Assess the importance of the external image of the bank. } \\
\hline \multicolumn{6}{|l|}{$\begin{array}{l}\text { Assess the importance of the product offering and its quality as well as the satisfaction of the } \\
\text { bank's customer. }\end{array}$} \\
\hline \multicolumn{6}{|l|}{ Assess the importance of the trust of the stakeholders with regard to the competition. } \\
\hline \multirow[t]{2}{*}{ Actions Which Improve Health in the Rural Area } & \multicolumn{3}{|c|}{ Very Low } & \multicolumn{2}{|c|}{ Very High } \\
\hline & 1 & 2 & 3 & 4 & 5 \\
\hline \multicolumn{6}{|l|}{$\begin{array}{l}\text { The importance given in the company to the CSR actions directed at improving the rural health } \\
\text { sector environment. }\end{array}$} \\
\hline \multicolumn{6}{|l|}{$\begin{array}{l}\text { The number of CSR actions which improve the rural health sector environment, which the } \\
\text { company has implemented. }\end{array}$} \\
\hline \multicolumn{6}{|l|}{$\begin{array}{l}\text { The level of social impact of the CSR actions which improve the rural health sector environment, } \\
\text { which the company carries out. }\end{array}$} \\
\hline \multicolumn{6}{|l|}{$\begin{array}{l}\text { The level of investment of CSR actions which improve the rural health sector environment taken by } \\
\text { the company. }\end{array}$} \\
\hline \multirow[t]{2}{*}{ Actions Which Improve Infrastructure and Environment in the Rural Area } & \multicolumn{3}{|c|}{ Very Low } & \multicolumn{2}{|c|}{ Very High } \\
\hline & 1 & 2 & 3 & 4 & 5 \\
\hline \multicolumn{6}{|l|}{$\begin{array}{l}\text { The importance given in the company to the CSR actions directed at improving infrastructure and } \\
\text { the environment in the rural area. }\end{array}$} \\
\hline \multicolumn{6}{|l|}{$\begin{array}{l}\text { The number of CSR actions which improve infrastructure and the environment in the rural area, } \\
\text { which the company has implemented. }\end{array}$} \\
\hline \multicolumn{6}{|l|}{$\begin{array}{l}\text { The level of social impact of the CSR actions which improve infrastructure and the environment in } \\
\text { the rural area, carried out by the company }\end{array}$} \\
\hline $\begin{array}{l}\text { The level of investment in CSR actions which improve infrastructure and the environment in the } \\
\text { rural area, which the company carries out. }\end{array}$ & & & & & \\
\hline
\end{tabular}

\section{References}

1. Habek, P. CSR Reporting Practices in Visegrad Group Countries and the Quality of Disclosure. Sustainability 2017, 9, 2322. [CrossRef]

2. Porter, M.; Kramer, M.R. Strategy and society: The link between competitive advantage and corporate social responsibility. Harv. Bus. Rev. 2006, 84, 78-92. [PubMed]

3. Yang, S.; Ye, H.; Zhu, Q. Do Peer Firms Affect Firm Corporate Social Responsibility? Sustainability 2017, 9, 1967. [CrossRef]

4. Singhapakdi, A.; Vitell, S.J.; Rallapalli, K.C.; Kraft, K.L. The Perceived Role of Ethics and Social Responsibility: A scale development. J. Bus. Ethics 1996, 15, 1131-1140. [CrossRef]

5. Fatma, M.; Rahman, Z. Consumer perspective on CSR literature review and future research agenda. Manag. Res. Rev. 2015, 38, 195-216. [CrossRef]

6. Simon, H. The Crisis and Customer Behavior: Eight Quick Solutions. J. Cust. Behav. 2009, 8, 177-186. [CrossRef]

7. Aguilera, R.V.; Rupp, D.E.; Williams, C.A.; Ganapathi, J. Putting the S back in Corporate Social Responsibility: A multilevel theory of social change in organizations. Acad. Manag. Rev. 2007, 32, 836-863. [CrossRef]

8. Matten, D.; Moon, J. "Implicit" and "explicit" CSR: A conceptual framework for a comparative understanding of corporate social responsibility. Acad. Manag. Rev. 2008, 33, 404-424. [CrossRef]

9. Schuler, R.; Jackson, S. Strategic Human Resource Management, 2nd ed.; Wiley-Blackwell: New York, NY, USA, 2006; ISBN 978-1-405-14959-4. 
10. Hambrick, D.C. Upper echelons theory: An update. Acad. Manag. Rev. 2007, 32, 334-343. [CrossRef]

11. Quazi, A.M. Identifying the determinants of corporate managers perceived social obligations. Manag. Decis. 2003, 41, 822-831. [CrossRef]

12. Porter, M.; Kramer, M. Creating share value. Harv. Bus. Rev. 2011, 89, 32-49.

13. McKinsey. Valuing Corporate Social Responsibility: McKinsey Global Survey Results; McKinsey Quarterly: New York, NY, USA, 2009.

14. Caruana, A.; Chircop, S. Measuring corporate reputation: A case example. Corp. Reput. Rev. 2000, 3, 43-57. [CrossRef]

15. Helm, S. The role of corporate reputation in determining investor satisfaction and loyalty. Corp. Reput. Rev. 2007, 10, 22-37. [CrossRef]

16. Olmedo, I.; Martínez, I.M.; Davies, G. Managing internal stakeholders' views of corporate reputation. Serv. Bus. 2014, 8, 83-111. [CrossRef]

17. Boshoff, C. A psychometric assessment of an instrument to measure a service firm's customer-based corporate reputation. S. Afr. J. Bus. Manag. 2009, 40, 35-49. [CrossRef]

18. Walsh, G.; Beatty, S.E. Customer-based corporate reputation of a service firm: Scale development and validation. J. Acad. Market. Sci. 2007, 35, 127-143. [CrossRef]

19. Camgöz Akdag, H.; Zineldin, M. Strategic positioning and quality determinants in banking service. TQM J. 2011, 23, 446-457. [CrossRef]

20. Thorsten, B.; Demirgüç-Kunt, A.; Levine, R. Law, endowments, and finance. J. Financ. Econ. 2003, 70, $137-181$.

21. Keh, H.T.; Xie, Y. Corporate reputation and customer behavioral intentions: The roles of trust, identification and commitment. Ind. Market. Manag. 2009, 38, 732-742. [CrossRef]

22. Boulouta, I.; Pitelis, C.N. Who needs CSR? The impact of corporate social responsibility on national competitiveness. J. Bus. Ethics 2014, 119, 349-364. [CrossRef]

23. Brammer, S.; Brooks, C.; Pavelin, S. Corporate social performance and stock returns: UK evidence from disaggregate measures. Financ. Manag. 2006, 35, 97-116. [CrossRef]

24. Lee, Y.K. A Comparative Study of Green Purchase Intention between Korean and Chinese Consumers: The Moderating Role of Collectivism. Sustainability 2017, 9, 1930. [CrossRef]

25. Varadarajan, R.; Menon, A. Cause-Related Marketing: A Coalignment of Marketing Strategy and Corporate Philanthropy. J. Market. 1998, 52, 58-74. [CrossRef]

26. Verbeeten, F.H.; Gamerschlag, R.; Möller, K. Are CSR disclosures relevant for investors? Empirical evidence from Germany. Manag. Decis. 2016, 54, 101-110. [CrossRef]

27. Droppert, H.; Bennett, S. Corporate social responsibility in global health: An exploratory study of multinational pharmaceutical firms. Glob. Health 2015, 11, 1. [CrossRef] [PubMed]

28. Quintás, J.R. Las Cajas de Ahorros en el Ámbito de la Responsabilidad Social Corporativa. Papeles de Economía Española 2006, 108, 128-143.

29. Pradhan, S.; Ranjan, A. Corporate social responsibility in rural development sector: Evidences from India. Sch. Dr. Stud. Eur. Union 2010, 139, 139-154.

30. Dutta, K.; Durgamohan, M. Corporate Social Strategy: Relevance and Pertinence in the Indian Context", Working Paper. 2008. Available online: www.iitk.ac.in/infocell/announce/conversion/papers (accessed on 21 March 2018).

31. Lind, D.A.; Marchal, G.M.; Wathen, S.A. Statistics Applied to Business and Economics, 15th ed.; McGrawHill: New York, NY, USA, 2012; ISBN 978-607-15-0742-6.

32. Osterman, P. How common is workplace transformation and how can we explain who adopts it? Ind. Labor Relat. Rev. 1994, 20, 986-1014. [CrossRef]

33. Das, S.K. Corporate Social Responsibility Initiatives Taken for Rural Development in India. Sumedha J. Manag. 2015, 4, 4-17.

34. Diamantopoulos, A.; Winklhofer, H. Index construction with formative indicators: An alternative to scale development. J. Market. Res. 2001, 38, 269-277. [CrossRef]

35. Chou, C.P.; Bentler, P.M.; Satorra, A. Scaled test statistics and robust standard errors for non-normal data in covariance structure analysis: A Monte Carlo study. Br. J. Math. Stat. Psychol. 1991, 44, 347-357. [CrossRef] [PubMed]

36. Hu, L.; Bentler, P.M. Fit Indices in Covariance structure modeling: Sensitivity to underparametrerized model misspecification. Psychol. Methods 1998, 3, 424-453. [CrossRef] 
37. Hair, J.F.; Sarstedt, M.; Ringle, C.M.; Mena, J. An assessment of the use of partial least squares structural equation modeling in marketing research. J. Acad. Market. Sci. 2011, 40. [CrossRef]

38. Masud, A.K.; Bae, S.M.; Kim, J.D. Analysis of Environmental Accounting and Reporting Practices of Listed Banking Companies in Bangladesh. Sustainability 2017, 9, 1717. [CrossRef]

39. Sofian, I.; Dumitru, M. The Compliance of the Integrated Reports Issued by European Financial Companies with the International Integrated Reporting Framework. Sustainability 2017, 9, 1319. [CrossRef]

40. Scholtens, B. Corporate social responsibility in the international banking industry. J. Bus. Ethics 2009, 86. [CrossRef]

(C) 2018 by the authors. Licensee MDPI, Basel, Switzerland. This article is an open access article distributed under the terms and conditions of the Creative Commons Attribution (CC BY) license (http://creativecommons.org/licenses/by/4.0/). 